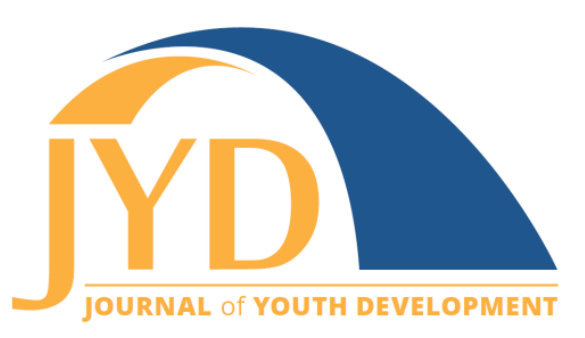

http://jyd. pitt. edu/ | Vol. 14 Issue 2 DOI 10.5195/jyd.2019.801 | ISSN 2325-4017 (online)

\title{
The Role of Youth Voice in This Special Issue
}

\author{
Aishia A. Brown \\ University of Louisville, School of Public Health \& Information Sciences \\ aishia.brown@louisville.edu
}

M. Gayle Gabriel

Texas A\&M University, Public Policy Research Institute

gaylegabriel@ppri.tamu.edu

\begin{abstract}
Youth voice has become a very popular term in youth development research and practice. However, there is a lack of critical dialogue surrounding the role of youth in the peer-review research process. This article explores the intersections of youth voice, marginalization in the peer-review research process, and the importance of utilizing a social justice youth development framework when reading the youth essays selected for this special issue.
\end{abstract}

Key words: immigrant, refugee, and border youth; youth voice; marginalization; youth engagement; social justice youth development

When young people learn to use their voice, great things can happen. Youth voice is one of the fundamental tenets of youth engagement (Zeldin, Gurtner, \& Chapa, 2018). It is essential for the staff of youth programs and youth to examine critically how youth voice is present, facilitated, and incorporated. Research suggests that when this happens and youth voice is taken seriously, youth can help organizations create authentic programs, policies and meaningful recommendations for their communities (Mitra, 2004; Mitra, Serriere, \& Kirshner, 2014; Schoenfeld, Bennett, Manganella, \& Kemp, 2018).

Although there has been a steady growth in the recognition of youth's unique perspectives, it is especially difficult to engage and make space for marginalized youth voices-such as those who are unfairly judged and stereotyped because of immigration, their documentation status, or

(cc) $\mathbf{E Y}$ New articles in this journal are licensed under a Creative Commons Attribution 4.0 License. This journal is published by the University Library System, University of Pittsburgh and is cosponsored by the University of Pittsburgh Press. The Journal of Youth Development is the official peer-reviewed publication of the National Association of Extension 4-H Agents and the National AfterSchool Association. 
The Role of Youth Voice

where they live. While many youth development practitioners are doing the noble work of including and advocating with and for such groups, movement can often be slow and filled with significant barriers.

Intensifying such marginalizations is the fact that youth voice stops short before the academic peer review process. Researchers and practitioners are often seen as the gatekeepers of knowledge who set high standards for entry into academic journals. As scholars in the field of youth development and as interdisciplinary collaborators, the next logical step in the empowerment of youth and the facilitation of their voices is to include their lived experiences and unique perspectives. This special issue has the opportunity to make such a space and elevate the voices of marginalized youth to both academic and national levels.

It is our hope that this landmark special issue will demonstrate the first step in the path toward integrated youth voice in the peer-review process and set precedence for the inclusion of immigrant, refugee, and border youth perspectives.

\section{Implications for Youth Development Researchers and Practitioners: The Importance of Social Justice Youth Development}

Youth development practitioners and researchers play critical roles in the lives of immigrant, refugee, and border youth. From cultivating spaces that promote social and emotional wellbeing to taking youth out of the country to gain new experiences, practitioners are of particular importance in the lives of marginalized youth. Practitioners are constantly adopting new and innovative approaches to youth engagement, programming, and services. We encourage practitioners, s one of the primary audiences of this journal, to engage with the youth essays by reading the text through a critical lens to transform their youth development practice. This involves reading and reflecting on how the youth describe the role of caring adults in their lives. These adults not only provide support to young people but are also deeply invested in providing experiences that help develop their cultural identities and commitment to their families and communities.

We also encourage youth development researchers reading this special issue to read the youth essays with the understanding that the lives of marginalized youth are often shaped by their culture, their communities, and the social, political, and economic systems they live under. As a result, youth development researchers reading this special issue should take a social justice 
youth development (SJYD) approach to engaging with the youth essays by considering the influence that systems have on youth who hold marginalized identities (Ginwright \& James, 2002; Outley, Brown, Gabriel, \& Sullins, 2018). Researchers should dig deep into understanding how systems like the education system may place additional burdens on refugee youth who are learning English as a second language or how the political system may cause border youth to be disconnected from their families and friends. Our goal for the youth essays selected to be in this special issue was to center the authentic lived experiences of immigrant, refugee, and border youth and we encourage researchers to adopt this approach in all aspects of their research process.

Youth development researchers and practitioners who submit to this journal add valuable insights on youth in many different communities and contexts. However, it is time to present well-rounded and deeply contextual accounts of what is going on in the immigrant, refugee, and border communities by juxtaposing peer-reviewed research and best practices with peerreviewed youth essays about their own experiences in these communities. The youth essays selected for this special issue highlight a multitude of experiences, perspectives, and new ways of knowing. We hope that this special issue not only improves youth development practices across the country but also provides meaningful context and illumination, as provided by the youth themselves, on what it means to be an immigrant, a refugee, or a young person living on the border.

\section{References}

Ginwright, S., \& James, T. (2002). From assets to agents of change: Social justice, organizing, and youth development. New directions for youth development, 2002(96), 27-46. doi:10.1002/yd.25

Mitra, D. L. (2004). The significance of students: can increasing "student voice" in schools lead to gains in youth development?. Teachers college record, 106(4), 651-688. doi:10.1111/j.14679620.2004.00354.x

Mitra, D., Serriere, S., \& Kirshner, B. (2014). Youth participation in U.S. contexts: Student voice without a national mandate. Children \& Society, 28(4), 292-304. doi:10.1111/chso.12005

Outley, C., Brown, A., Gabriel, M., \& Sullins, A. (2018). The role of culture in out-of-school time settings. In P. A. Witt \& L. L. Caldwell (Eds.), Youth development principles and practices in out-of-school time settings (pp. 463-492). Retrieved from https://www.researchgate.net/profile/Peter_Witt5/publication/323389633_Youth_Development_P rinciples_and_Practices_in_Out-of- 
Journal of Youth Development | http://jyd.pitt.edu/ | Vol. 14 Issue 2 DOI 10.5195/jyd.2019.801

The Role of Youth Voice

School_Time_Settings/links/5abe51a645851584fa719e3b/Youth-Development-Principles-andPractices-in-Out-of-School-Time-Settings.pdf?origin=publication_detail

Schoenfeld, E. A., Bennett, K., Manganella, K., \& Kemp, G. (2018). More than just a seat at the table: The power of youth voice in ending youth homelessness in the United States. Child Care in Practice, 25(1), 112-125. doi:10.1080/13575279.2018.1521376

Zeldin, S., Gurtner, J., \& Chapa, B. (2018). Preparing for youth engagement: Youth voice, youth-adult partnership, youth organizing. Ithaca, NY: Act for Youth Center for Community Action: Practice Matters. Retrieved from http://actforyouth.net/resources/pm/pm_preparing-youthengagement_0818.pdf 